\title{
MRIにて造影効果の消長を繰り返した悪性グリオーマの1例
}

\author{
片 岡桃子浅田裕幸小嶋康弘北村 創*
}

\section{A Case of Malignant Glioma showing Atypical Magnetic Resonance Imaging Findings con- sisting of the Repeated Appearance and Disappearance of Gd-DTPA Enhancement}

by

\author{
Momoko Kataoka, M.D., Hiroyuki Asada, M.D., Yasuhiro Kojima, M.D., and \\ Kin Kitamura, M.D.*
}

from

Department of Neurosurgery, Kanazawa Hospital, and

* Department of Pathology, Yokohama Minamikyosai Hospital

A 40-year-old man was admitted to our institute with convulsions. Magnetic resonance imaging (MRI) on admission demonstrated a tumor mass in the right fronto-parietal region that showed as hypointense on the $\mathrm{T1} 1^{-}$ weighted images and hyperintense on the $\mathrm{T} 2$-weighted images, without enhancement by gadolinium-diethylenetriaminepenta-acetic acid (Gd-DTPA). Serial MRI showed localized enhancement in the posterior rim of the tumor 1 month later, which subsequentry disappeared a month later. Subtle enhancement in the deep posterior portion of the tumor appeared 3 months later, which again vanished 1 month later. His convulsions subsequently occurred more frequently, and he developed left hemiparesis. Therefore, a biopsy of the mass was performed through a craniotomy 10 months after admission. MRI just before the operation showed enhancement in the lateral rim of the tumor. The histological diagnosis was anaplastic astrocytoma according to the World Health Organization Classification. This case of repeated appearance and disappearance of enhancement on MRI is unique.

(Received May 25, 2000 ; accepted September 12, 2000)

Key words : malignant glioma, gadolinium-DTPA, magnetic resonance imaging, blood-brain barrier Jpn J Neurosurg (Tokyo) $10: 348^{-352,2001}$

\section{はじめに}

一般的に悪性脳腫瘍のMRIに掞ける造影効果は腫瘍 そのものではなく，腫場内毛細血管の透過性の程度，す なわち血液脳関門の破壞した部位を示し，一度造影効果 が出現すると，腫瘍の進行に伴い造影部位の進展を認め 消失することはない(1)4)5)8) 16)222.

今回われわれは悪性グリオーマでMRIにて造影効果 の消長を繰り返した稀な症例を経験したので報告する.

\section{症 例}

患 者：40歳, 男性

現病歴：1997年6月, 左顔面の病攣発作で発症し来院 した.

入院時所見：神経学的に異常を認めなかった.

神経放射線学的所見：頭部 CT では右前頭頭頂葉に不 整形，低吸収の造影効果のない腫瘍性病変を認めた。単 純 MRI では同部位に $\mathrm{T} 1$ 強調画像で低信号, T2 強調画像 で高信号の病変を認めた（Fig. 1)。造影MRIでは初診

景翠会金沢病院脳神経外科／干236-0004 横浜市金沢区泥亀2-8-3〔連絡先：片岡桃子〕

Address reprint requests to: Momoko Kataoka, M.D., Department of Neurosurgery, Kanazawa Hospital, 2-8-3 Deiki, Kanazawa-ku, Yokohama-shi, Kanagawa 236-0004, Japan

*横浜南共済病院病理 


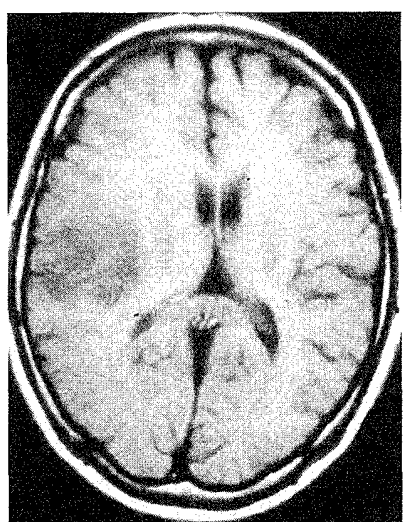

$\frac{\mathrm{A}}{\mathrm{B}}$

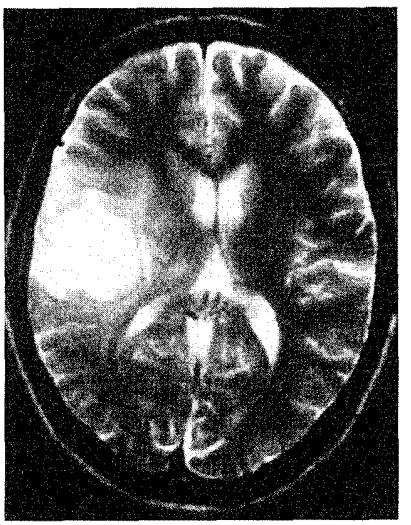

Fig. 1 Preoperative MR images show the mass in the right fronto- parietal region as hypointense on the T1weighted image (A) and hyperintense on the $\mathrm{T} 2-$ weighted image (B).
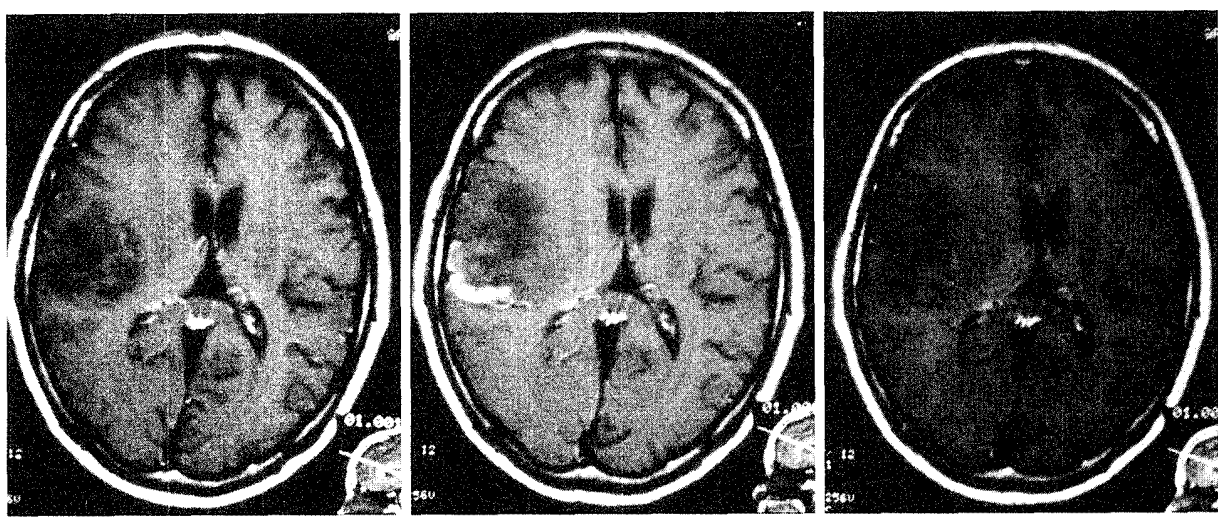

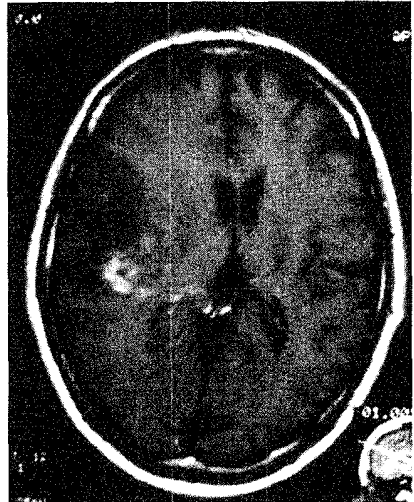

$\mathrm{A}|\mathrm{B}| \mathrm{C}$ D $/ \mathrm{E} / \mathrm{F}$

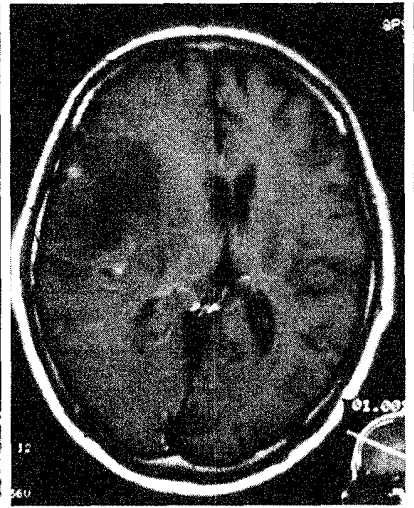

Fig. 2 MR images

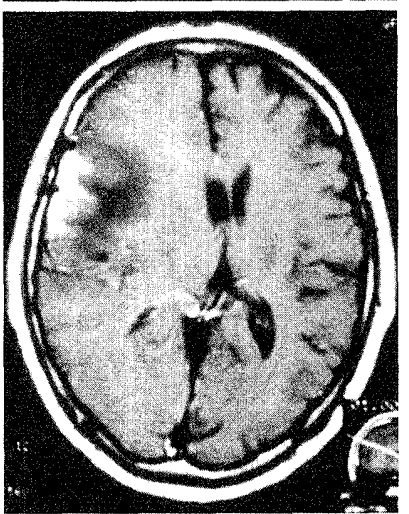

A $\sim \mathrm{C}:$ Preoperative T1-weighted MR image on admission with gadolinium-diethylenetriaminepenta-acetic acid, showing no enhancement (A). One month later, localized enhancement was observed mainly in the posterior rim of the tumor along the cortex (B), by the next month, this enhancement had disappeared $(\mathbb{C})$.

D, E: Follow-up MR image 3 months later showed subtle enhancement in the deep posterior portion of the tumor $(\mathbb{D})$, which again vanished 1 month later $(\mathbf{E})$.

$\mathrm{F}$ : Three months later just before the operation, enhancement was seen in the lateral rim of the tumor $(\mathbf{F})$

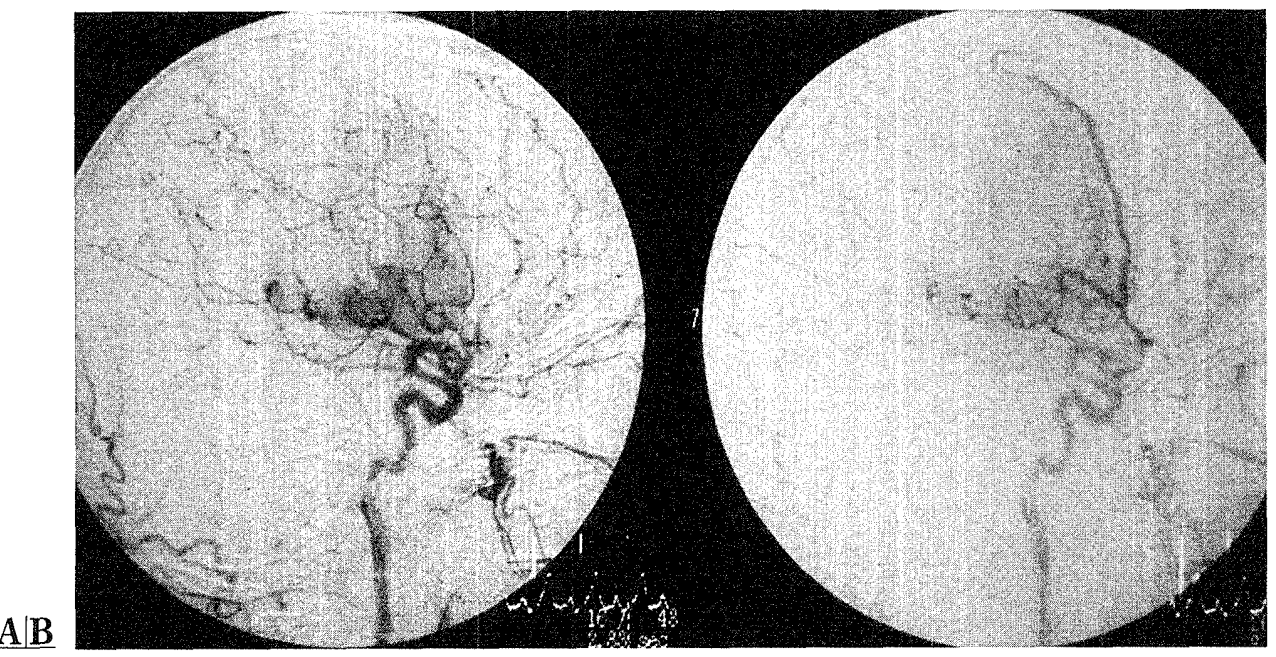

Fig. 3 Right carotid angiograms, early (A) and late (B) arterial phase, show tumor staining and arteriovenous shunting.

時には増強効果はなく，1力月後の7月 23 日，腫瘍後方 辺縁の皮質に沿って増強効果を認めたが，1力月後に消 失した。12月 10 日さらに腫瘍深部後方に不規則な增強
効果を認めたが，1力月後に消失した（Fig. $2 \mathrm{~A} 〜 \mathrm{E} ） 。 こ$ の間ステロイドや浸透圧性利尿薬は使用していない. ま た，㽷攣は抗症攣薬で抑えられており，普通に仕事をし 


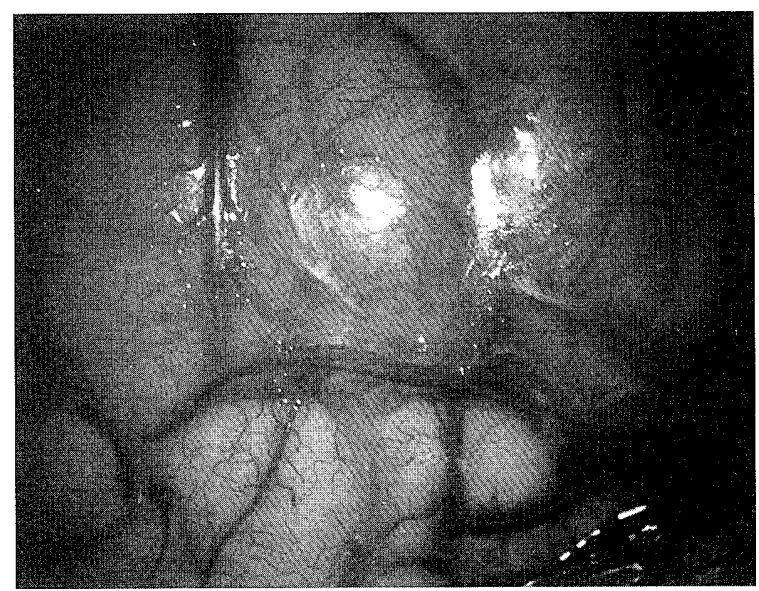

Fig. 4 Intraoperative photograph showing the swollen cortex overlying the tumor with numerous delicate red veins and a large draining vein
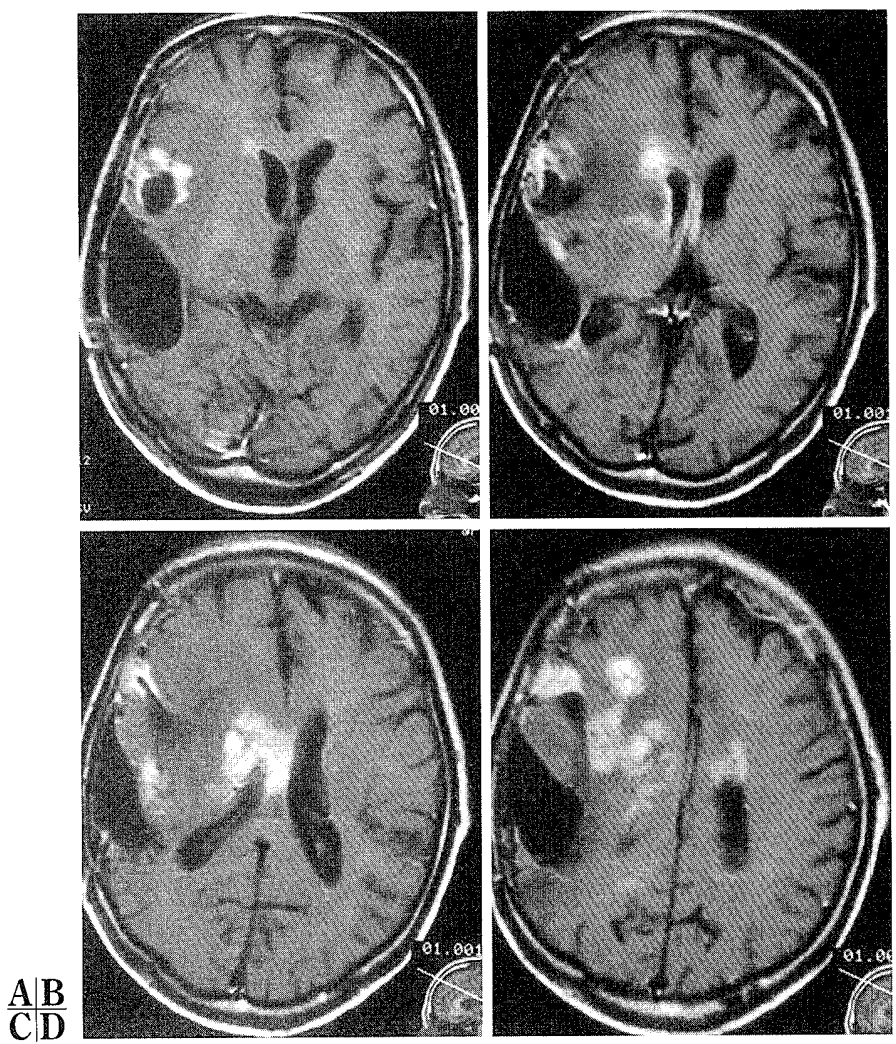

Fig. 6 T1-weighted MR images with gadolinium obtained 11 months after the operation demonstrating a heterogeneous mixed intensity mass infiltrating across the genu of the corpus callosum

Multifocal and irregular ring enhancement patterns with large areas of internal necrosis are characteristic of malignant glioma.

\section{ていたため手術をせず経過観察した。}

1998 年 4 月 6 日，MRIで腫陽外側辺縁の皮質に沿って 新たな増強効果を認めた（Fig. $2 \mathrm{~F})$ 。血管造影では tumor staining および anteriovenous shuntingを認めた
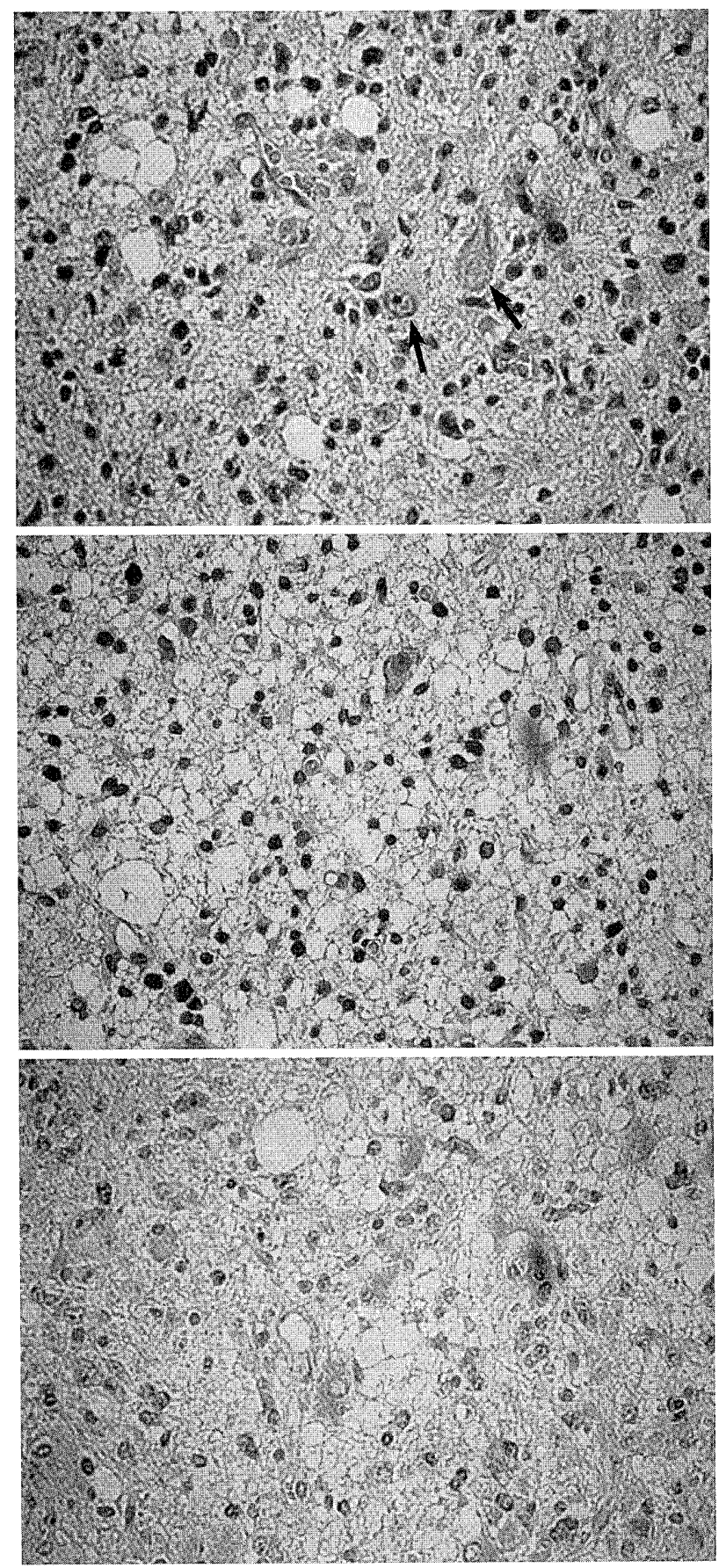

Fig. 5 A: Photomicrograms of the tumor specimen shows tumor cells infiltrating among the nerve cells (arrows), without destruction of the preexisting parenchyma ( $\mathrm{H} \& \mathrm{E}$ stain, $\times 200)$.

B : Another specimen shows fibrillary appearance $(\mathrm{H}$ \& E stain, $\times 200)$.

$\mathrm{C}$ : Immunohistochemical staining for glial fibrillary acidic protein shows a positive reaction in some of the tumor cells $(\times 200)$.

(Fig. 3)。その後痓攣発作が増加し, 左不全片麻㽻が出 現したため，4月21日，開頭生検術を施行した。

手術所見：シルビウス裂を含む右頭頂側頭開頭を行っ た。脳は頭頂葉を中心にび漫性に腫脹し，脳表はhyper- 
emicで多数の red veinを認めた（Fig. 4)，正常にみえる 部位も含め数力所生検した。細かいveinを避け，慎重 に生検したが 12 時間後，急性脳浮腫による herniation signを呈したため, 内外減圧術を施行した。

病理所見：腫瘍細胞が結節を作らず，組織の構築を保 ちつつ神経細胞の間をび漫性に増殖している部分と fibrillary な部分が混在していた。一部に核分裂像を認めた。 血管周囲には perivascular cuffing がみられた。腫瘍細胞 の胞体・細胞突起はGFAPに陽性であった，以上より WHO 分類の anaplastic astrocytoma と診断した（Fig. 5).

術後経過：放射線 total $60 \mathrm{~Gy}$ 照射し，左不全片麻盘を 残すも独歩退院した。 月 1 回のインターフェロン療法を 施行していたが徐々に腫瘍が増大し，1999年1月，食事 摂取困難となり再入院した。

3 月の MRI で cystの周囲，前頭葉，脳室周囲，脳梁に 沿って対側にも増強効果を認め，典型的な畫性グリオー マの所見を呈していた（Fig. 6)。4月19日，全身状態が 悪化して死亡した。腫洦発見から死亡までの経過は 22 カ月であった。

\section{考 察}

今回，経過観察中，造影 MRI て病変辺縁の皮質に 沿って異なる部位に増強効果の消長を繰り返したため, 脳梗塞 ${ }^{12)}$ 20), 脱髄性病変9) 10) 14) 17) 19), 炎症性病変2) 6), 悪性リンパ腫等も疑ったが，病理学的に悪性グリオーマ と診断したきわめて稀な症例を経験した。グリオーマ系 の腫瘍においてステロイドや浸透圧性利尿薬の投与によ り，CTやMRIで造影効果が縮小したという例は報告さ れている3(8)18)，本症例では，造影効果が消長を繰り返 した期間に，これらの薬刘は使用しておらず，また造影 部位が場所を変えて出現，消失したという意味で興味深 い，本来，脳実質由来の腫瘍において，造影剤による増 強効果は腫瘍そのものではなく，血液脳関門が破綻し血 管の透過性が光進した状態を示す8)，血液脳関門の本体 は内皮細胞であり，正常では tight junctionを有するため， 血管内の物質が脳実質に移行するのを防いでいる 瘍により新生された血管では通常の脳内毛細血管と異な り fenestrationをもち tight junction 認めないので，一 度増強効果が出現すると消失することはない4），一方， 可逆性の造影効果を示す脱髄性病変では，増悪期にリン パ球から放出されるサイトカインにより活性化した内皮 細胞に接着分子が発現し，これを介して血管内物質が内 皮細胞を通過するが，寛解期にはこの変化が消失す

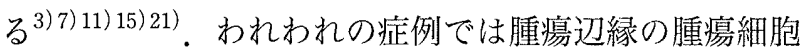

の浸潤活性が最も高いと考えられる部位で次々と新たに 造影効果の出現, 消失を繰り返した. グリオーマの浸潤 にも各種のサイトカインにより発現が増強される接着分 子が関与しているが，この部の内皮細胞で脱髄性病変と 同様な変化を起こしているという報告はない13)。われわ れの症例で増強効果の消長を繰り返した原因は不明であ るが，腫瘍辺縁の浸潤部位で腫瘍細胞の密度の低い部位 ではまだ真の意味での腫湯血管が新生しておらず，ここ で脱髄性病変や炎症性病変に類似した内皮細胞の可逆性 変化が起こったのではないかと考えた。なお，造影剤の 量, および造影剤投与後の造影時間は常に一定であった。 以上より，このような画像上の経過をとった場合も, 鑑 別診断としてグリオーマも考慮すべきである.

\section{文 献}

1) Brasch $\mathrm{RC}:$ Work in progress : Methods of contrast enhancement for NMR imaging and potential applications. Radiology 147: 781-788, 1983.

2) Davidson HD, Steiner RE: Magnetic resonance imaging in infections of the central nervous system. AJNR $\quad 6: 499-$ 504, 1985.

3) Dore-Duffy P, Newman W, Balabanov R, Lisak RP, Mainolfi E, Rothlein R, Peterson M : Circulating, soluble adhesion proteins in cerebrospinal fluid and serum of patients with multiple sclerosis: Correlation with clinical activity. Ann Neurol 37: 55-62, 1995.

4) Gold RL, Dillon WR Jr: Magnetic resonance imaging. in Berger MS, Wilson CB (eds) : The Gliomas, 1st ed., Philadelphia, WB Saunders, 1999, pp.275-293.

5) Graif M, Bydder GM, Steiner RE, Niendorf P, Thomas DG, Young IR : Contrast-enhanced MR imaging of malignant brain tumors. AJNR $\quad \mathbf{6}: 855-862,1985$.

6) Haimes AB, Zimmerman RD, Morgello S, Weingarten $K$, Becker RD, Jennis R, Deck MDF : MR imaging of brain abscesses. AJR 152: 1073-1085, 1989.

7) Hartung HP, Reiners K, Archelos JJ, Michels M, Seeldrayers P, Heidenreich F, Pflughaupt KW, Toyka KV: Circulating adhesion molecules and tumor necrosis factor receptor in multiple sclerosis: Correlation with magnetic resonance imaging. Ann Neurol 38: 186-193, 1995.

8) Herbert HE, Dennis GG: The blood-brain barrier : Structure, function, and response to neoplasia. in Berger MS, Wilson CB (eds) : The Glioma, Ist ed., Philadelphia, WB Saunders, 1999, pp.115-121.

9) Kermode AG, Thompson AJ, Tofts P, MacManus DG, Kendall BE, Kingsley DPE, Moseley IF, Rudge P, McDonald WI: Breakdown of the blood-brain barrier precedes symptoms and other MRI signs of new lesions in multiple sclerosis: Pathogenetic and clinical implications. Brain 113: 1477-1489, 1990.

10) Kermode AG, Tofts PS, Thompson AJ, MacManus DG, Rudge P, Kendall BE, Kingsley DP, Moseley IF, du Boulay EPGH, McDonald WI: Heterogeneity of blood-brain barrier changes in multiple sclerosis: An MRI study with gadolinium-DTPA enhancement. Neurology $\quad 40: 229-$ $235,1990$. 
11) Kwon EE, Prineas JW: Blood-brain barrier abnormalities in longstanding multiple sclerosis lesions: An immunohistochemical study. J Neuropathol Exp Neurol 53:625-636, 1994.

12) McNamara MT, Brant-Zawadzki M, Berry I, Pereira B, Weinstein P, Derugin N, Moore S, Kucharczyk W, Brasch $\mathrm{RC}$ : Acute experimental cerebral ischemia: MR enhancement using Gd-DTPA. Radiology 158: 701-705, 1986.

13) Mikkelsen T, Rosenblum ML: Tumor Invasiveness. in Berger MS, Wilson CB (eds) : The Glioma, ed 1. Philadelphia, WB Saunders, 1999, pp.76-86.

14) Miller DH, Rudge P, Johnson G, Kendall BE, Macmanus DG, Moseley IF, Barnes D, McDonald WI: Serial gadolinium enhanced magnetic resonance imaging in multiple sclerosis. Brain 111: 927-939, 1988.

15) Pober JS: Warner-Lambert/Parke-Davis award lecture. Cytokine-mediated activation of vascular endothelium: Physiology and pathology. Am J Pathol 133:426-433, 1988.

16) Rippe DJ, Boyko OB, Fuller GN, Friedman HS, Oakes WJ, Schold SC : Gadopentetate-dimeglumine-enhanced MR imaging of gliomatosis cerebri: Appearance mimicking leptomeningeal tumor dissemination. AJNR 11:800-801,
1990.

17) Stone LA, Smith ME, Albert PS, Bash CN, Maloni H, Frank JA, McFarland HF : Blood-brain barrier disruption on contrast- ${ }^{-}$nhanced MRI in patients with mild relapsing-remitting multiple sclerosis: Relationship to course, gender, and age. Neurology 45:1122-1126, 1995.

18）鈴木謙介, 鶴嶋英夫, 吉井与志彦, 山田雄三, 坪井康次, 能勢忠男：一過性に画像学的軽快をみた anaplastic astrocytomaの1例. 脳外 25:661-664, 1997.

19) Thompson AJ, Miller D, Youl B, MacManus D, Moore S, Kingsley D, Kendall B, Feinstein A, McDonald WI: Serial gadolinium-enhanced MRI in relapsing/remitting multiple sclerosis of varying disease duration. Neurology 42:6063, 1992.

20) Virapongse C, Mancuso A, Quisling R: Human brain infarcts: Gd-DTPA-enhanced MR imaging. Radiology 161: 785-794, 1986.

21) Wakefield AJ, More LJ, Difford J, McLaughlin JE : Immunohistochemical study of vascular injury in acute multiple sclerosis.J Clin Pathol 47: 129-133, 1994.

22) Yanaka K, Kamezaki T, Kobayashi E, Matsueda K, Yoshii $\mathrm{Y}$, Nose T: MR imaging of diffuse glioma. AJNR 13 : $349-351,1992$.

要

旨

MRIにて造影効果の消長を繰り返した悪性グリオーマの1例

片岡 桃子 浅田 裕幸 小嶋 康弘 北村 創

症例は 40 歳, 男性で, 左顔面の痙攣発作で発症した．初診時の MRIで右前頭頭頁葉に $T 1$ 強調画像 で低信号, T2 強調画像で高信号の造影効果のない腫瘍性病変を認めた，その後, 9カ月の間に腫湯の 辺縁の皮質に沿って異なる部位に造影効果の出現, 消失を繰り返した. その間痙孌発作の頻度が徐々 に増加し左不全片麻楿が出現したため, 初診 10 力月後開頭生検術を施行し anaplastic astrocytoma と 診断した．悪性グリオーマで造影効果の消長を繰り返した症例の報告はなく，稀な症例と考え報告し た. 